\title{
Perspectives of Special Education: Literature Review and Interview
}

\author{
Elizabeth Block, Mary Breaud, Caroline McNulty, Tiffany Papa, Mistie Perry \\ College of Education and Behavioral Sciences, Nicholls State University, Thibodaux, USA \\ Email: tiffany.papa@nicholls.edu
}

How to cite this paper: Block, E., Breaud, M., McNulty, C., Papa, T., \& Perry, M. (2019). Perspectives of Special Education: Literature Review and Interview. Creative Education, 10, 1973-1981. https://doi.org/10.4236/ce.2019.109143

Received: August 14, 2019

Accepted: September 8, 2019

Published: September 11, 2019

Copyright $\odot 2019$ by author(s) and Scientific Research Publishing Inc. This work is licensed under the Creative Commons Attribution International License (CC BY 4.0).

http://creativecommons.org/licenses/by/4.0/

\section{(c) (i) Open Access}

\begin{abstract}
This article provides historical and present-day perspectives on special education including a review of current literature as well as data collected from a face-to-face interview with a special education leader at an elementary school in south Louisiana. The interviewee offered rich insight and first-hand knowledge regarding placement of students with disabilities in inclusive school settings. Based on the interview responses, two themes emerged in response to the overarching question of how do SPED teachers and leaders create success for students with learning differences? These themes include: 1) the SPED environment and 2) approaches of successful SPED teachers. The data within these themes suggest that the interviewee perceives inclusion to be the greatest advancement in the field of special education as his experiences describe the beneficial aspects of the inclusion classroom setting for students with disabilities. These experiences have contributed to his belief that one day all classrooms in every school will be inclusive in nature.
\end{abstract}

\section{Keywords}

Special Education, Leadership, Disabilities, Inclusion

\section{Introduction}

Special education is a form of education that focuses on the needs of students with disabilities and learning differences. Groundbreaking laws and policies that were implemented in the last 50 years have transformed special education into what it is today with inclusion at the forefront. In order to provide a framework for continuous improvement in the area of special education, a review of the literature regarding its history over the last 50 years is offered. Special educator perspectives are relevant as these individuals have first-hand knowledge of what practices work best for students with disabilities. Through an interview with a 
SPED teacher and leader, the authors explore the overarching question of how SPED teachers and leaders create success for students with disabilities.

\section{A Historical Approach to Special Education}

Historically, students with disabilities were isolated from the general population of students and placed in self-contained special education classrooms which only housed special education students. Present-day special education practices are vastly different from the practices of the past. A series of significant historical events profoundly transformed the practice of special education. In 1975, the Education for All Handicapped Children Act (National Education Association of the United States, 1978) was signed by President Gerald Ford. It required public schools to provide free education to children with mental and physical handicaps. This law ensured that availability of special education services to children in need and guaranteed that decisions about services for students with disabilities were fair and appropriate. It also established specific management and auditing requirements for special education while providing federal funds to help states educate students with disabilities (Block \& Carter, 2016).

In 1997, the Individuals with Disabilities Education Act (IDEA) were signed by President Bill Clinton providing positive changes to the Education for All Handicapped Children's Act. IDEA ensured that both regular and special needs students have access to the same high-quality curriculum (US Department of Education, 2007) and guaranteed that students with Individualized Education Programs (IEPs), participation in the Least Restrictive Environments (LREs), and requires qualified teachers for students with disabilities. Building on this legislation, the No Child Left Behind Act was signed in 2001 by President George W. Bush to ensure the best education for low income and disabled students. $\mathrm{He}$ stated that the Department of Education was committed to ensuring that all children-including children with disabilities-receive a high-quality education (US Department of Education, 2004). Before IDEA, if students with special needs were not spending their days in an institution, they were segregated from their peers at district schools in separate classrooms run by teachers who were not properly trained in special education (US Department of Education, 2007).

Great strides have been made in the field of special education in the last 50 years to evolve to the current special education practices of less segregation and more integration. IDEA requires that a continuum of placement options be available to meet the needs of students with disabilities (Anderson, 2018). The law ensures that to the maximum extent appropriate, children with disabilities should be educated with children who are typically developing. Special classes, separate schooling or removal of children with disabilities from typically developing peers occurs only when education cannot be attained satisfactorily with the use of supplementary aids and services (Classroom Leadership, 2001). Students with disabilities are spending less time isolated from their peers and more time interacting and socializing in general education classrooms known as inclusion classrooms. From 1989-2010, there was a 90 percent increase in the time 
special education students spent in inclusion classrooms (Anderson, 2018). These inclusive classrooms afford both special education students and traditional students more instructional time, fewer absences, better post-secondary outcomes, and increased social benefits for both populations as students learn to better relate to diverse populations (Anderson, 2018).

The perspectives of special educators and their leaders are vital to positive change in advancing the practice of inclusion. These perceptions and experiences provide a crucial lens through which educators and researchers may view inclusion theory and literature. Educators must be multifaceted to properly run an effective inclusive classroom and meet the needs of a diverse student population. Teachers have created inclusive classrooms conducive to learning by consulting Individualized Education Programs (IEPs), relaying content in diverse ways, using various approaches for processing information, incorporating life skills training into lessons, collaborating with other teachers, and following a flexible behavior plan (Special Education Guide, 2019). These positive changes have taken place in both inclusion classrooms and special education leadership positions. A special education leader has clear responsibilities for understanding the ever changing laws and regulations and working closely with state departments of education on compliance and monitoring. They are responsible for ensuring that students with disabilities are provided a high-quality education. Additionally, they evaluate the special education staff to ensure that special education students are making progress (Bateman \& Cline, 2019).

Significant legislation over the past 50 years has transformed special education and brought awareness to the best practices of inclusive classrooms. Perspectives and experiences of special educators are essential in creating a foundation for continuous improvement in the field. To obtain this first-hand knowledge, an interview with a special education leader was conducted in order to gain insight into the field of special education. The interview questions were aligned with the literature with regard to best practices in inclusive settings, federal regulations and challenges inherent to the field.

\section{Methodology}

\subsection{Setting and Participant}

A face-to-face interview with a leader in special education was conducted in April of 2019 at an elementary school located in south Louisiana. The special education leader has 29 years of experience as an educator, 20 of which were as a special education teacher within a local school district and the last nine years as a special education leader within the same school district. He was selected due to accessibility and his extensive years of experience in special education. In addition, the interviewee has received regional and state recognition for his contributions to the field of special education.

\subsection{Questionnaire}

The interview questions were developed by the authors in order to obtain the 
interviewee's insights regarding his experiences in special education. Twelve questions were developed as extensions from special education literature with the overarching goal of discerning how do SPED teachers and leaders perceive special education as well as how special education teachers create success for all students with learning differences? Based on the literature, the authors including the following: 1) What are your job responsibilities? 2) What are your past work experiences? 3) What is your philosophy regarding special education? 4) How have you implemented this philosophy? 5) What major changes have you seen throughout your career in special education? 6) What are your thoughts on recent SPED initiatives? 7) What is your approach to collaborative teaming in SPED? 8) What were the rewards of being a special educator? 9) What are the challenges of being a special education leader? 10) What is the state of special education with regard to inclusive settings? 11) What do you see in the future of early childhood special education? 12) What advice would you give to a new teacher in special education? These questions were designed as a cursory probe into the perspectives of a SPED leader. Interview questions and responses may be found in Appendix A.

\subsection{Procedure}

In April of 2019, the selected interviewee was contacted and asked if he would meet for a face-to-face interview in order to gather his insights regarding the field of special education. The interviewer met in the interviewee's office in the school district for approximately one hour. The interviewer posed 12 questions and recorded the responses on a voice memo app on her mobile device while taking hand-written notes.

\section{Results}

Interview responses were transcribed from the interviewer's notes and mobile recording (see Appendix A). From the 12 posed questions, two main themes emerged (see Table 1) as support for the overarching question: how do SPED teachers and leaders create success for students with disabilities? The first theme

Table 1. Overarching question: how do SPED teachers and leaders create success for students with disabilities?

\begin{tabular}{ll}
\hline \multicolumn{1}{c}{ Theme: SPED Environment } & Theme: Approaches to Successful SPED Teachers \\
\hline Most natural environment & Multi-faceted approach to education \\
Least restrictive environment & Collaborative teaming \\
$\begin{array}{l}\text { Environments that expose students to } \\
\text { new learning and new experiences }\end{array}$ & Team approach in delegating tasks \\
$\begin{array}{l}\text { Growth found in moving from } \\
\text { self-contained to inclusive classrooms }\end{array}$ & $\begin{array}{l}\text { Flexibility and growth: change is inevitable, response } \\
\text { to change is significant }\end{array}$ \\
$\begin{array}{l}\text { Student growth in inclusion classrooms } \\
\text { Continued advocacy of inclusion classrooms }\end{array}$
\end{tabular}


that emerged was the SPED Environment with the following responses categorized within: 1) most natural environment; 2) least restrictive environment; 3) environments that expose students to new learning and new experiences; 4) growth found in moving from self-contained to inclusive classrooms; and 5) student growth in inclusion classrooms. The second theme that emerged from the interview is approaches for successful SPED teachers including: a) multi-faceted approach to education; b) collaborative teaming; c) team approach in delegating tasks; d) flexibility and growth with response to change as significant; and e) continued advocacy of inclusion classrooms.

\section{Discussion}

The responses were then analyzed in conjunction with the literature to obtain a more thorough understanding of the field of special education from the vantage point of a special education leader. The interview offered insight into how special education has evolved and how inclusive settings will continue to evolve in the years to come. Responses that supported theme one (SPED environment) included the interviewee's greatest reward in becoming a SPED teacher; that of student growth. He stated that special education is extremely gratifying to him because of the growth that he observes in his students as they overcome various obstacles. Based on his experiences, the interviewee believes that inclusive settings are the most beneficial settings in which to see growth among students with disabilities. He stated that he is extremely satisfied that today's model of special education is the inclusion classroom and in most cases, placing special education students in inclusion classrooms is the most effective way to meet their needs. Just as Anderson (2018) found a reciprocity in social growth for special needs and regular education children within inclusive classrooms, the interviewee also shared his experiences with these multi-directional benefits for all students.

The second emerging theme found in the interview centered on the approaches of successful SPED teachers. The interviewee stated the biggest challenge of a special educator and/or special education leader is the continuously changing federal regulations. Keeping current with the changing laws and policies with regard to special education and the implementation of these laws and policies is a challenge that necessitates flexibility. He also shared that learning to be flexible is the advice he gives to new teachers; "Regulations are always changing; rules are always changing; and IEPs continuously change. Never get too complacent. If you learn to evolve with the job, you will be successful." In addition to flexibility, the interviewee shared that SPED teachers and leaders must engage in collaborative teaming in order to provide students with all available resources. The interviewee explained that by providing special education students with everything they need to be successful, whether it be specialty educators, therapists, school psychologists and/or nurses, they are given an equal opportunity to learn and grow in their most natural environment. Furthermore, the interviewee 
agrees with the multi-faceted approach of assisting the students with disabilities in a variety of ways in order to help them reach their full potential.

\section{Limitations}

This study contained several limitations. One special education teacher/leader whose experiences have been specific to one district was interviewed. In the future, input from multiple SPED teachers/leaders across school districts should be sought in a focus group format allowing for greater depth of data collection leading to greater generalizability of results. In addition, the interview questions were not based on existing survey tools and questions were designed as a cursory dive into perceptions of a SPED teacher/leader. Future survey questions should be piloted prior to implementation and consist of a narrower focus on the two themes that emerged from this study.

\section{Future Implications}

The history of special education has been wrought with the seclusion and labeling of children with disabilities. To address this challenge, advocates in the field of education have championed policies for children with special needs over the last 50 years, transforming the landscape of special education. This study prompts future investigation of SPED teachers'/leaders' perceptions of inclusion classrooms as well as the skills identified as crucial in creating success for students with disabilities. Future exploration of the two themes identified in this study will expand the strategies and tools that are perceived as useful and subsequently help to support other teachers and professionals provide effective guidance and instruction to students with disabilities. The interviewee in this study stated that the schools in his district typically only have two inclusion classrooms out of every five non-inclusion classrooms in any given grade level. Future examination of SPED teachers' strategies and real-world experiences may prompt policy makers to expand the resources available to special education so that every classroom in every grade level will be considered an inclusion classroom.

\section{Conclusion}

The field of special education has made incredible progress since it was founded fifty years ago. "In the early 1970s, multiple landmark court decisions provided states with the responsibility to provide special education resources and schooling to students with special needs. These decisions altered the entire landscape of special education history in our country" (All Education Schools, 2018). Through the literature review and interview process, the authors found that incredible progress has been made in the field of education. Students with special needs are fully integrated into regular education inclusion classrooms. In order to manage an effective inclusive classroom, the authors believe that educators must be multifaceted and develop their abilities to meet the needs of a diverse student population. Thus far, special educators have created classrooms condu- 
cive to inclusive learning by consulting Individualized Education Programs (IEPs), relaying content in diverse ways, using various approaches for processing information, incorporating life skills training into lessons, collaborating with other teachers, and following a flexible behavior plan (Special Education Guide, 2019). Special Education is ever-changing and as it continues to improve, the need for leaders educated in special needs is imperative.

\section{Conflicts of Interest}

The authors declare no conflicts of interest regarding the publication of this paper.

\section{References}

All Education Schools (2018). A Brief History of Special Education in the United States. https://www.alleducationschools.com/blog/history-of-special-education

Anderson, A. (2018). Inclusive Classrooms: Looking at Special Education Today. http://inservice.ascd.org/inclusive-classrooms-looking-at-special-education-today

Bateman, D., \& Cline, J. (2019). Special Education Leadership: Building Effective Programming in Schools. New York: Routledge. https://doi.org/10.4324/9781351201353

Block, M., \& Carter, E. (2016). A Meta-Analysis of Educator Training to Improve Implementation of Interventions for Students with Disabilities. Remedial and Special Education, 38, 131-144. https://doi.org/10.1177/0741932516653477

Classroom Leadership (2001). Including Students with Disabilities in General Education Classrooms. Schools and the Law, 5.

http://www.ascd.org/publications/classroom-leadership/dec2001/Including-Students-w ith-Disabilities-in-General-Education-Classrooms.aspx

National Education Association of the United States (1978). P.L. 94-142: Related Federal Legislation for Handicapped Children and Implications for Coordination. Washington DC: The Association.

Special Education Guide (2019). The General Ed Teacher's Guide to the Inclusive Classroom.

https://www.specialeducationguide.com/pre-k-12/inclusion/the-general-ed-teachers-gu ide-to-the-inclusive-classroom

US Department of Education (2004). A Guide to Education and No Child Left Behind. https://www2.ed.gov/nclb/overview/intro/guide/guide_pg20.html\#disab

US Department of Education (2007). Twenty-Five Years of Progress in Educating Children with Disabilities through IDEA.

https://www2.ed.gov/policy/speced/leg/idea/history.pdf 
Appendix A. SPED Leader Questions and Answers

Prompt

What are your job responsibilities?

What are your past work experiences?

What is your philosophy regarding special education?

How have you implemented this philosophy?

What major changes have you seen throughout your career in special education?
"I am an elementary special education coordinator in charge of elementary special educators within the local school district."

"I have been in the education system for 29 years. I was a Special education teacher for 20 years and has been a SPED leader for the last 9 years."

"My philosophy has always been that all children learn and grow best in their most natural environments." As a special education teacher, and now a leader in his own elementary school, the interviewee stated that he believes "all children learn and grow best in their most appropriate setting and that is the environment with the least restrictions." His philosophy stems from the belief that students with special needs must be given experiences with regular education children, as these experiences benefit all children in inclusion classrooms. The interviewee has implemented this belief by striving to make sure the special education students in his care were exposed to "new learning and new experiences" in inclusion settings.

"As a SPED educator and now a SPED leader, I have always pushed to make sure my students with special needs were in environments that exposed them to new learning and new experiences and that the teachers that are responsible for them, do the same. With some of the more severely disabled students, extra staff and classroom resources may not be enough and them and they may need to be placed into a resource room for certain portions of the school day in order to afford the special education staff the opportunity to work with the students more directly."

When asked about the changes the interviewee has seen throughout his career in Special Education, he explained that "in the past, special needs classrooms were not included in regular education schools." In the beginning of his career, these classrooms were secluded from everyone. "There was not a lot of education going on. Then, special education classrooms were opened in regular schools, but these students weren't interacting well with others. Finally, these students were integrated into regular education classrooms, otherwise termed inclusive classrooms which seemed to make a significant difference in the growth of students with exceptionalities and their typically developing peers." He has seen incredible strides made on behalf of these students, from seclusion to complete inclusion. 


\section{Continued}

What are your thoughts on recent SPED initiatives?

What is your approach to collaborative teaming in SPED?

What were the rewards of being a special educator?

What are the challenges of being a special education leader?

What is the state of special education with regard to inclusive settings?

What do you see in the future of early childhood special education?

What advice would you give to a new teacher in special education?
"Giving special needs students everything they need to be successful, whether it be occupational therapy, physical therapy, adapted physical therapy, or inclusion, are the current trends and I am in full agreement with this multi-faceted approach."

"Great leaders usually have a team of people supporting them." When asked about his team for special education students, the interviewee explained that a team should be "well-balanced and represent all areas of [Special Education]. Representatives in nursing, psychology, pupil appraisal, occupational therapy, adapted physical therapy, physical therapy, and legal representation creates an ideal team of professionals."

The interviewee stated that professions full of challenges often produce great rewards and one of his greatest rewards is witnessing student growth. "Kids are like sponges. They grow so much every day. The job is instantly gratifying because you get to see so much growth.” Through his past experience, he stated that he has seen such growth in students that are part of inclusion classrooms. The current development in Special Education is more inclusion, with resource rooms used as "a way to remediate what is taught in regular [education] classrooms.”

"Federal regulations. The small class size ratios of adults to children, the strict daily schedules, and the endless paperwork are all challenges." However, he stated that after he learned how to "delegate responsibilities and multitask" he was able to better manage the challenges and overcome them. "Delegating responsibilities, multitasking, and prioritizing duties are principles all educators strive to perfect."

"Inclusion is the way of the future. The leaders at the top want every student in an inclusion setting with regular ed children. Currently we typically only have 2 inclusion classrooms out of 5 in any given grade level. I believe this will increase to all as we progress."

"A lot more inclusion classrooms... possibly every classroom will be inclusive. A lot more children will participate in inclusion in regular classrooms. SPED will service these children in those classrooms."

"I would say to be flexible! Regulations are always changing, rules are always changing, and IEPs constantly change. Never get too used to the way things are going. Learn to evolve with the job and you'll be successful." 